Hawker, L. E. \& Fraymouth, J. (1951). J. gen. Microbiol. 5, 369-386.

\title{
A Re-investigation of the Root-Nodules of Species of Elaeagnus, Hippophae, Alnus and Myrica, with Special Reference to the Morphology and Life Histories of the Causative Organisms
}

\author{
LILIAN E. HAWKER AND JOAN FRAYMOUTH \\ Department of Botany, University of Bristol
}

SUMMARY: Root-nodules of Elaeagnus spp., Hippophae rhamnoides, Alnus glutinosa and Myrica gale are modified lateral roots. The enlarged cortical cells of an actively growing nodule contain the endophyte in several stages of development. The apical meristem is free from infection but the cells just behind it show a plasmodial stage. In older parts of the nodules, spherical vesicles are formed in species of Elaeagnus, Hippophae and Alnus and club-shaped bodies in Myrica and from these small, bacteroid-like granules are produced. There is some evidence that granules formed in different host cells fuse in pairs and possess some ability to migrate within the nodule and into the soil. No definite hyphae can be seen in any of the nodules, but well-marked protoplasmic strands or lines of flow are present, particularly in the endophyte of Myrica.

The controversial views of earlier writers are discussed, and it is concluded that the nodule organisms are members of the Plasmodiophorales.

The conflicting opinions of earlier workers on the nature of the endophytes in the root-nodules of certain non-leguminous plants made a re-investigation desirable. Accordingly, nodules from roots of Elaeagnus macrophylla Thbg., $\boldsymbol{E}$. angustifolia L. (E. hortensis M. Bieb), Hippophae rhamnoides L., Alnus glutinosa (L.) Gaertn. (A. rotundifolia Stokes) and Myrica gale L. were examined throughout the year by means of squash preparations, hand sections, and freezing-microtome sections of fresh material; and variously stained microtome sections of material fixed in Craf II (see Sass, 1940, p. 19) and embedded in paraffin wax. The most useful general stain was carbol fuchsin counterstained with light green. Aniline blue in lactic acid was also used. For cytological details gentian violet, alone or counterstained with light green, or iron alum haematoxylin, alone or similarly counterstained, were used. Other stain combinations were tried but gave no further information. Gram-staining gave variable results.

The observations of earlier workers (Servettaz, 1909) on the morphology of the nodules were confirmed. In all species examined the nodules are modified lateral roots. The swelling begins at the base of the young lateral and the nodule afterwards forks and may eventually produce a large compound gall. The young nodules have no root-hairs and are enclosed in a cork coat of two to three layers of cells. In Myrica the tips of the roots remain free from infection; they become cut off by the cork layer and are eventually sloughed off. When soil conditions are suitable the tips of the modified roots of the other species resume growth and break through the outer cork layer. They can then be seen as white tips to the branches of the nodules. 
Elaeagnus macrophylla, E. angustifolia and Hippophae rhamnoides

In active nodules of these three species the endophyte is most conspicuous in the cortical cells just behind the growing apex. Here the infected cells are enlarged and filled with the endophyte. The infected lateral shows at least three zones corresponding with the stage of development of the parasite (Pl. 1, figs. 1, 2), and this may account for the varied descriptions met with in the literature. In the extreme tip of the nodule the host cells are not infected, are normal in shape and the walls are thin and entire (Fig. 1a). Just behind this uninfected growing tip the cortical cells are not completely filled with the endophyte which is seen as an amorphous mass of naked protoplasm surrounding the host nucleus (Fig. $1 b, c$ ). Further back from the tip, where the infection is presumably more advanced, some cells show the host nucleus pushed to one side with the remains of the host protoplast which is in process of absorption by the parasite (Fig. 2; Pl. 1, fig. 3). Other cortical cells are completely filled with an undifferentiated mass of protoplasm which resembles the plasmodium of Plasmodiophora. The nucleus of the host cell remains more or less intact for some time after the rest of the cell contents have been absorbed, but later becomes distorted and is finally also absorbed. Delicate protoplasmic strands which pass through the host cell walls connect the 'plasmodia' in neighbouring cells (Fig. $1 b, c$ ). Observations of this 'plasmodial' zone immediately behind the apical meristem of the infected root suggest that the endophyte advances with the seasonal growth in length of the nodule by penetrating the cell walls and becoming established in the young cells shortly after they are formed. The 'plasmodia' of the parasite appear to flow through the pierced wall of an infected cell into a younger and hitherto uninfected one, the nucleus of which is soon surrounded.

In the second and most conspicuous zone of the infected area, situated on the side of the plasmodial zone remote from the apex of the nodule, the majority of the host cells are each filled with a cluster of small spherical bodies (diam. about $4 \mu$.) embedded in a network of protoplasm, derived from the plasmodium, which may be connected by protoplasmic strands with that in neighbouring cells (Fig. 1 $f$; Fig. 2; Pl, 1, fig. 3). In some cells these bodies may be seen in process of differentiation. At this stage preparations stained with gentian violet or iron alum haematoxylin show numerous minute nuclei in process of division (Fig. 1d; Fig. 3; Pl. 1, fig. 4). These are so small that the method of division could not be determined with certainty, but the presence of an equatorial dark-stained band suggests a normal nuclear division. This division is simultaneous throughout the contents of a single host cell and takes place very rapidly since it is seen only in a few cells in any one section and is not always present. At a slightly later stage the protoplasm of the plasmodium becomes aggregated into dense spherical masses which later become surrounded by clear areas or walls (Fig. $1 e-g$ ). When such a mass is seen free from host tissue in gently squashed hand or freezing microtome sections of fresh material, the spherical bodies separate slightly from one another and single specimens on the periphery of the mass appear to give rise to minute particles 
$(<0.5 \mu$. dia.) which move away sluggishly leaving the collapsed vesicle. In sections of fixed material the contents of the cluster of spheres stain deeply with gentian violet or iron alum haemotoxylin. These deeply stained masses
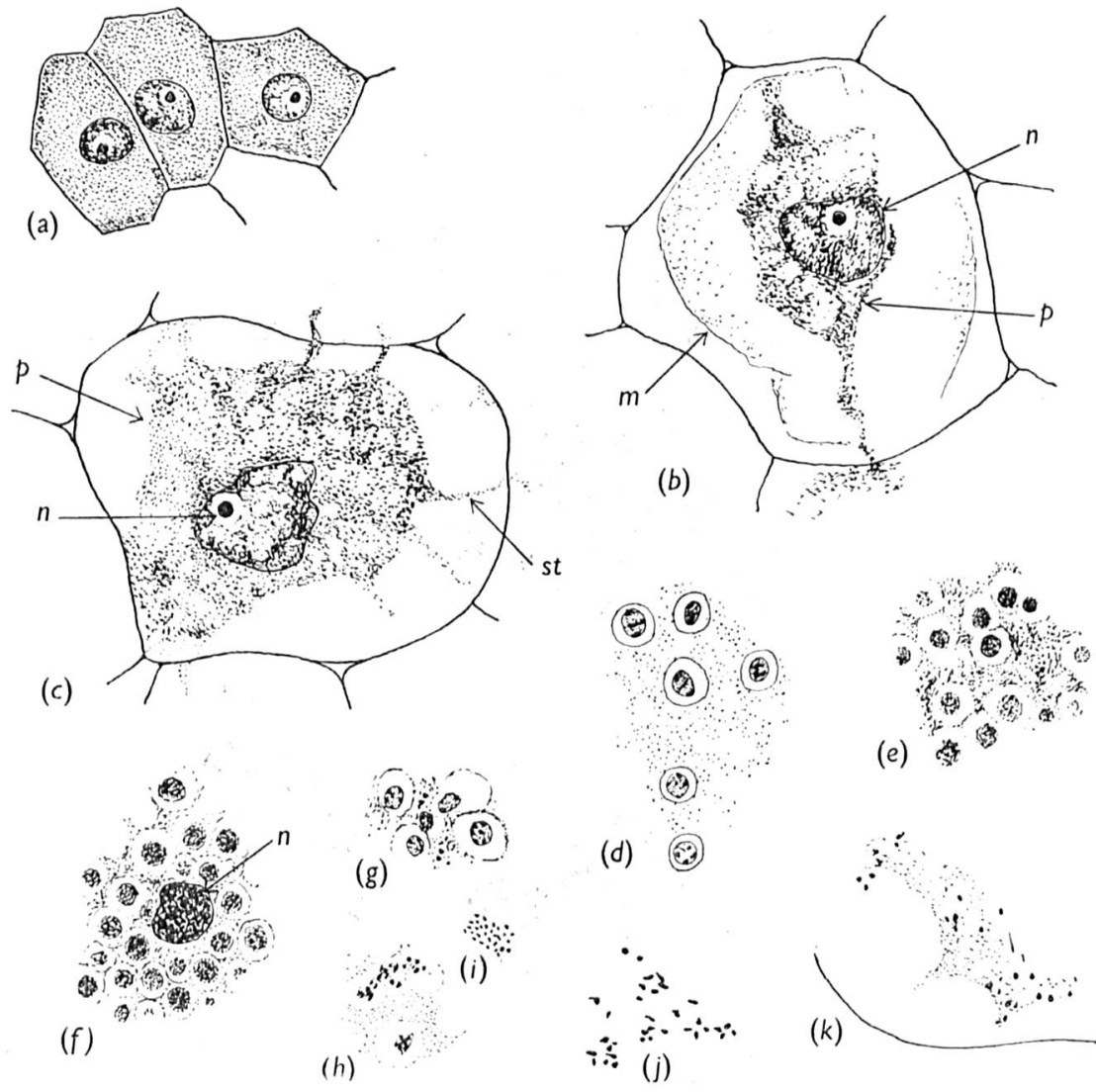

Fig. 1. Hippophae rhamnoides. Stages in development of endophyte. a, uninfected meristematic cells from apex of nodule. $\quad b$, cell from zone behind apex (zone $P, P l .1$, fig. 1) showing young plasmodium $(p)$ which has entered cell through a small pore in the wall and has surrounded the host nucleus $(n) .(m)$ remains of plasma membrane. $c$, cell from same zone, slightly more advanced stage of infection. Plasmodium $(p)$ half-filling cell, host nucleus $(n)$ showing erosion. Strands (st) extending to host cell walls and into adjacent cells. $d$ to $f$, stages in the formation of sporangia (zone $S$ of Pl. 1, fig. 1). $d$, shows dividing nuclei of endophyte. $e$, later stage in the formation of sporangia. $f$, deformed host nucleus $(n)$, surrounded by mature sporangia. $g$, shows presence of definite 'bacteroid'-like particles or granules in sporangium. $h$, shows these escaping from sporangium. $i$, shows the escaped 'bacteroids'. $j$, shows larger bodies which may be the result of conjugation of the original granules. $k$, shows disintegrating remains of endophyte from zone $D$ (Pl. 1, fig. 1), with a few bacteroids still present. (All drawings $\times$ 1200.)

are at first regularly granular and finally break up unto small particles $(<0 \cdot 5 \mu$. diam.) which are liberated (Fig. $1 h-i$ ). Empty collapsed vesicles, comparable to those seen in fresh squashed material, can also be seen in the stained sections (Fig. 2). The small bodies liberated from a cluster of vesicles flow in a muci- 
laginous mass into neighbouring cells and intercellular spaces. Examples have been noted where the mucilaginous masses from different cells flow together and in these intermingled masses the granules are approximately twice the size of the newly liberated ones (Fig. $1 j$ ), suggesting a conjugation of granules derived from different clusters. At this stage the walls of the host cells show a change in nature, indicated by an alteration in staining properties, and are often partly disintegrated and absorbed.

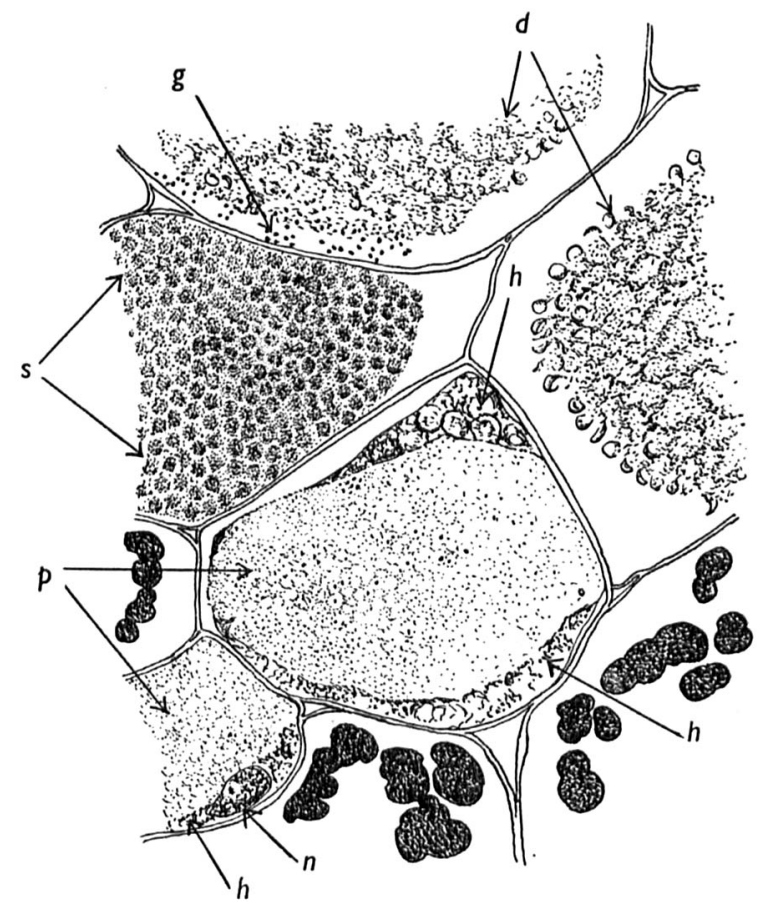

Fig. 2. Elaeagnus macrophylla. Stages in development of endophyte (from same slide as Pl. 1, fig. 3). Plasmodium $(p)$ nearly filling host cell and beginning to form sporangia, $(h)$ remains of host cytoplasm, $(n)$ host nucleus, $(s)$ young sporangia, $(d)$ disintegrating remains of plasmodia and sporangia with some bacteroid-like granules $(g)$ escaped from sporangia. The nodule from which this section was cut was not actively growing (see p. 373) and the zonation was thus less distinct than in Pl. 1, fig. 2. Dark amorphous masses in some cells are host contents. $\times \mathbf{5 5 0}$.

The third zone of the infected part of the nodule lies at the base and its extent depends on the age of the nodule. Here the host cells are almost empty and the walls are much broken and disintegrated. In the cells nearest the active zone of infection disintegrating remains of collapsed vesicles (Fig. $1 k$ ) and protoplasmic strands may be seen, but further towards the base of the nodule few traces of the endophyte remain. It is not clear what becomes of the parasite at this stage. The most likely explanation is that the bulk of the protoplasm of the organism is used up in the formation of the small particles and that these escape into the soil by some means. These minute bodies are readily washed out of microtome sections during staining once they have escaped from the host cell in which they were formed, and they are too small to be identified with 
any certainty in fresh unstained material. In some of the preparations of Hippophae, however, these granules were observed in cracks in the cork coat at the base of the nodules whence they might be expected to pass out into the soil. Such cracks frequently arise as a result of renewed growth of the nodule following a return of favourable soil conditions, and it may well be that the granules normally escape in this way. In Elaeagnus the cells of each zone are not so uniformly infected as in Hippophae, and neighbouring cells which have

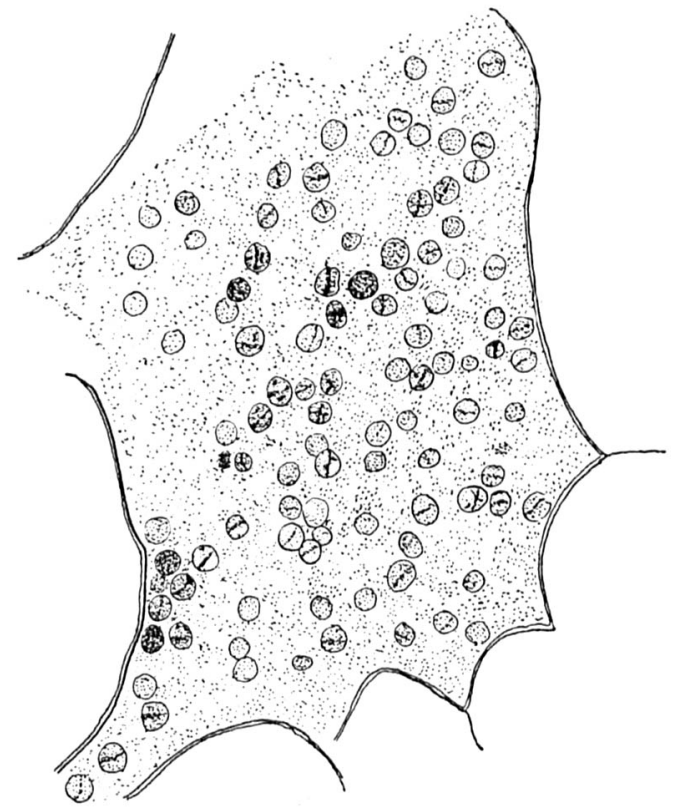

Fig. 3. Elaeagnus angustifolia. Nuclear divisions in plasmodium (from same slide as Pl. I, fig. 4). Fully developed plasmodjum of endophyte showing nuclear divisions (probably meiotic). $\times 1000$.

hitherto escaped infection are invaded by the granules and a 'plasmodium' subsequently develops. It is also possible that the protoplasm of the plasmodium stage may flow out into the soil as such masses of protoplasm have occasionally been seen in cracks in the cork coat of the nodule. There is no means of determining whether such a mass is entering or escaping from the nodule. A similar migrating plasmodium has been figured by Schaede (1933) in a root-nodule of Alnus japonica, and is interpreted by him as showing penetration of the endophyte into the nodule, despite the fact that the nodule is already infected.

Whatever the method by which the endophyte escapes from mature nodules into the soil it is clear that young lateral roots become infected from the soil as they emerge from the surface of the parent root. There is a short period when the region just behind the root cap is quite unprotected. A cell completely filled with the invader has been seen in this position when there was no trace of the endophyte in either the parent root or the extreme tip of the rootlet. The invading organism probably obtains entry in the form of a free-moving particle from the soil. 


\section{Alnus glutinosa}

The endophyte in root-nodules of Alnus is again confined to the cortex behind the growing point, but it occurs in tangentially-arranged plates of cells separated by normal ones containing large compound starch grains and others containing a dark amorphous substance (Pl. 2, fig. 1). The latter resemble the tannin cells characteristic of tree roots infected with ectotrophic mycorrhiza-forming fungi, and their presence suggests a host reaction to the presence of the invader whose migrations are thus restricted.

The morphology and life history of the endophyte are essentially similar to those of the endophytes of Elaeagnus and Hippophae. The vesicles are larger $(6 \mu$. diam.) and a bigger proportion of the protoplasm is used up in their formation so that instead of being embedded in a network of protoplasm they are attached to fine strands, giving them the appearance of a bunch of toy balloons (Fig. 4; Pl. 2, fig. 1). This is particularly clear in expressed fresh material (Fig. 5). The connecting strands of protoplasm linking the bunches of vesicles in adjacent cells are more substantial than those of the endophytes of Elaeagnus and Hippophae, but still have no definite cell wall and are too irregular in size and shape to be interpreted as hyphae.

The granules are more readily liberated from the vesicles in fresh material, when they tend to form a dense 'halo' round the expressed endophyte, than in the other two species. They are also seen more frequently in stained preparations of alder nodules (Pl. 2, fig. 2) than in those of Elaeagnus and Hippophae, but this may be due to greater resistance of the host walls to attack so that escape and migration of the granules are more difficult. Granules are frequently seen in the intercellular spaces, however, and the doubling of their size, presumably as a result of conjugation, has been most clearly seen in this species (Fig. 6).

\section{Myrica gale}

The endophyte in root-nodules of $\boldsymbol{M}$. gale shows some important differences from those of the hosts already considered. It occurs throughout the cortex and shows a somewhat similar zoning of the infected area, but the parasite has a particularly striking effect upon the cells of the host at an early stage of infection. Invaded cells are much enlarged, the nucleus is rapidly absorbed, and the walls are altered so that they give a yellow reaction with aniline chloride which suggests lignification, as pointed out by Schaede (1939). The invading organism has difficulty in penetrating these walls. Passage of the plasmodium from one cell to another takes place by way of small pores in the host wall which have presumably been made by the invader (Fig. $7 b$ ). Frequently funnels of host-wall material extend into the cell from the pore (Fig. $7 c-e ;, \mathrm{Pl} .2$, fig. 3) and are no doubt a host reaction to penetration, reminiscent of that seen in response to the penetration of clover by Rhizobium leguminosarum (Thornton, 1949) and of various plants by such fungi as Erysiphe polygoni. The result is that at each cross-wall the plasmodium is restricted to a narrow channel and oozes through the pore in a thick stream 


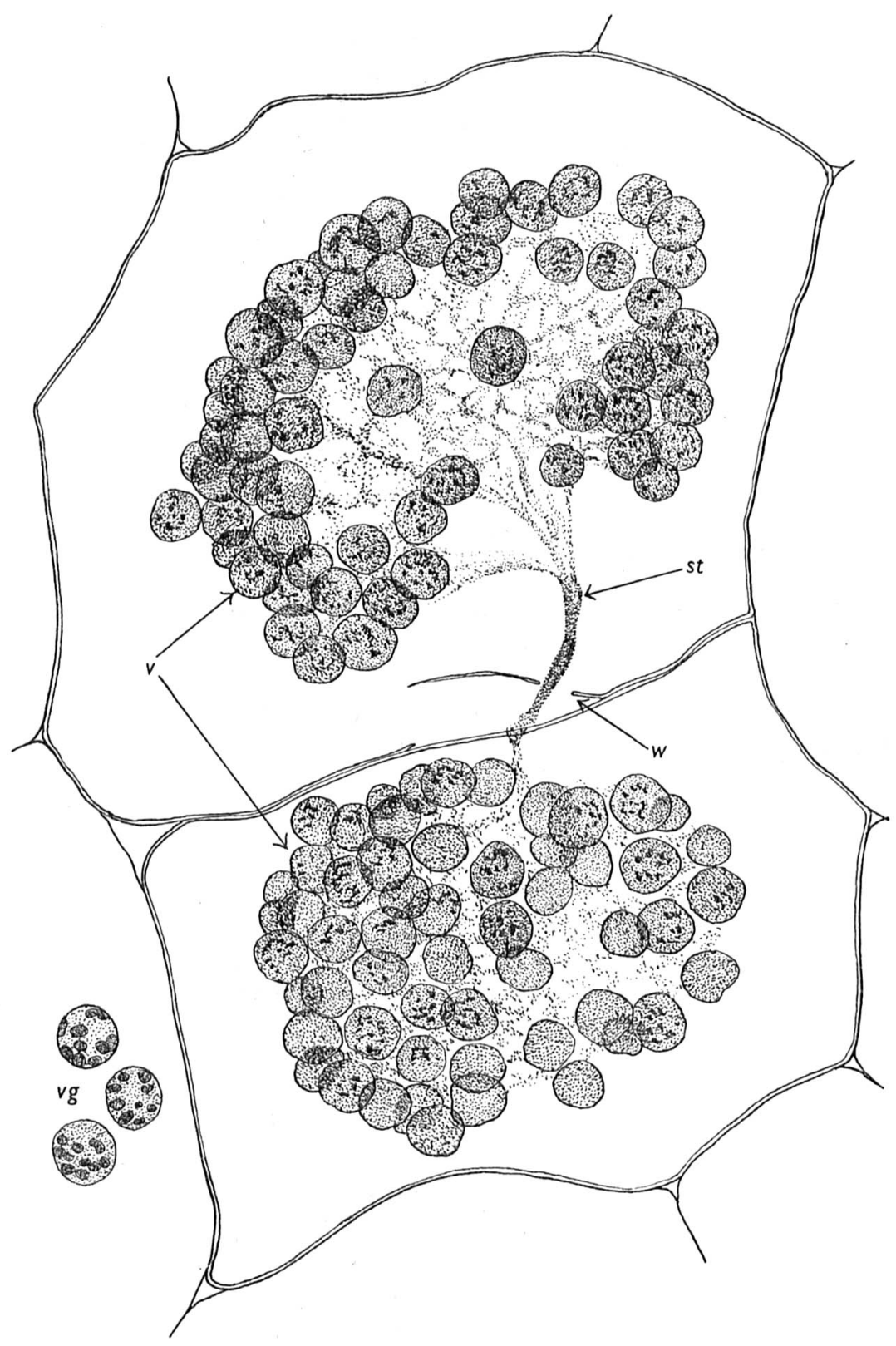

Fig. 4. Alnus glutinosa. Vesicular stage of endophyte. Vesicles (sporangia (v)) of endophyte in longitudinal sections of cells of root-nodule. Note connecting strands of protoplasm $(s t)$, broken cell wall of host $(w)$ at point where connecting strands pass through. $(v g)=$ slightly older vesicles showing formation of granules. $\times 1050$. 


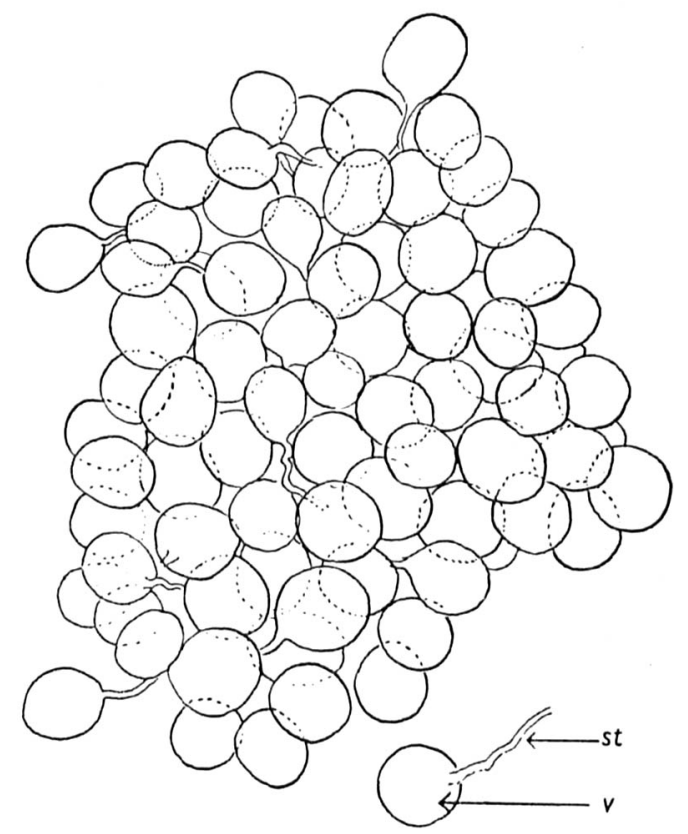

Fig. 5. Alnus glutinosa. Fresh material, squash preparation. Mass of vesicles (sporangia) of endophyte freed from host cell by gentle squashing. $(v)=$ single vesicle; note attached protoplasmic strand $(s t) . \quad \times 1050$.

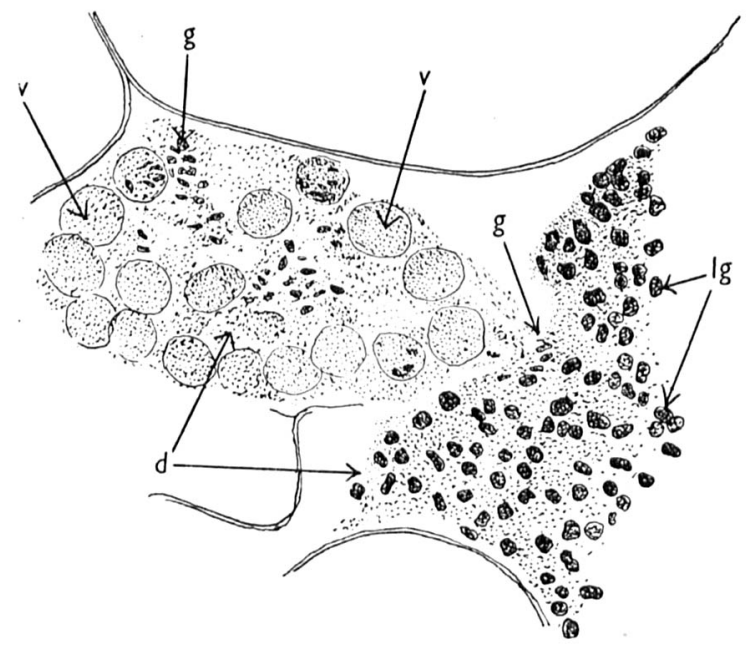

Fig. 6. Alnus glutinosa. Migrating granules of endophyte. Empty vesicles $(v)$ of endophyte. 'Bacteroid'-like granules $(g)$ which have escaped from the vesicles, and larger granules (lg) which are probably the result of conjugation of the smaller ones. $(d)$ disintegrating remains of reticulate plasmodium. $\times 1000$. 
which continues across the cell to the opposite wall and which may often be traced through several cells in one section (Fig. $7 a-c ;$ Pl. 2, fig. 3). Elongated deeply staining granules are sometimes seen oriented in a direction parallel to

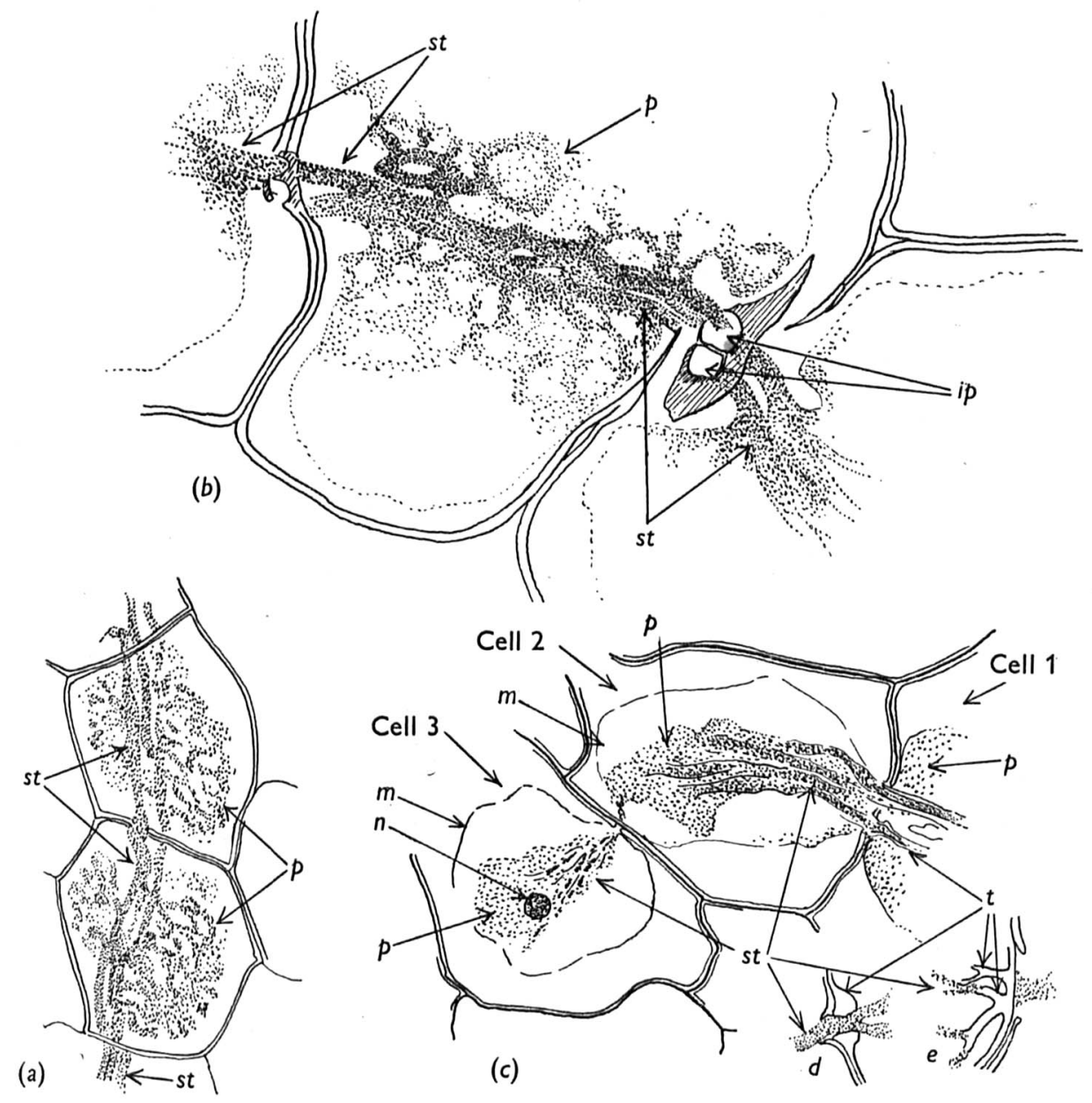

Fig. 7. Myrica gale. Plasmodia and protoplasmic strands of endophyte. (a) plasmodium of endophyte. st, protoplasmic strands or 'lines of flow' which pass through cell walls of host and fan out to fill cell with a reticulate mass of protoplasm (plasmodium, $p$ ). $\times \mathbf{9 0 0}$. (b) similar stage showing infection pores $(i p)$ in host cell wall. Wall is disintegrating. $\times$ 1500. ( $c$ cells shown in Pl. 2, fig. 3. Note host nucleus $(n)$ and plasma membrane $(m)$ in cell 3, 'lines of flow' or protoplasmic strands of endophyte $(s t)$ and tubular outgrowths $(t)$ from host cell wall in response to presence of parasite. $\times 900$. $d$ and $e$ show similar lignified outgrowths of cell wall of host which confine the plasmodium in its passage from cell to cell. $\times \mathbf{9 0 0}$.

the direction of flow of the protoplasm, as would be expected. The plasmodium fans out from this central strand to fill the periphery of the host cell with an amorphous or somewhat reticulate mass of protoplasm.

Instead of the spherical vesicles seen in the previously described organisms, club-shaped structures develop at the periphery of the plasmodium of the 
Myrica endophyte (Fig. 8a; Pl. 2, fig. 4). These stain deeply and uniformly with gentian violet, but their contents are seen to be granular in preparations stained with iron alum haemotoxylin (Fig. $8 b$ ). There is no distinct membrane surrounding them as round the vesicles of the other parasites considered here, and the club-shaped bodies break up into packets of small particles resembling
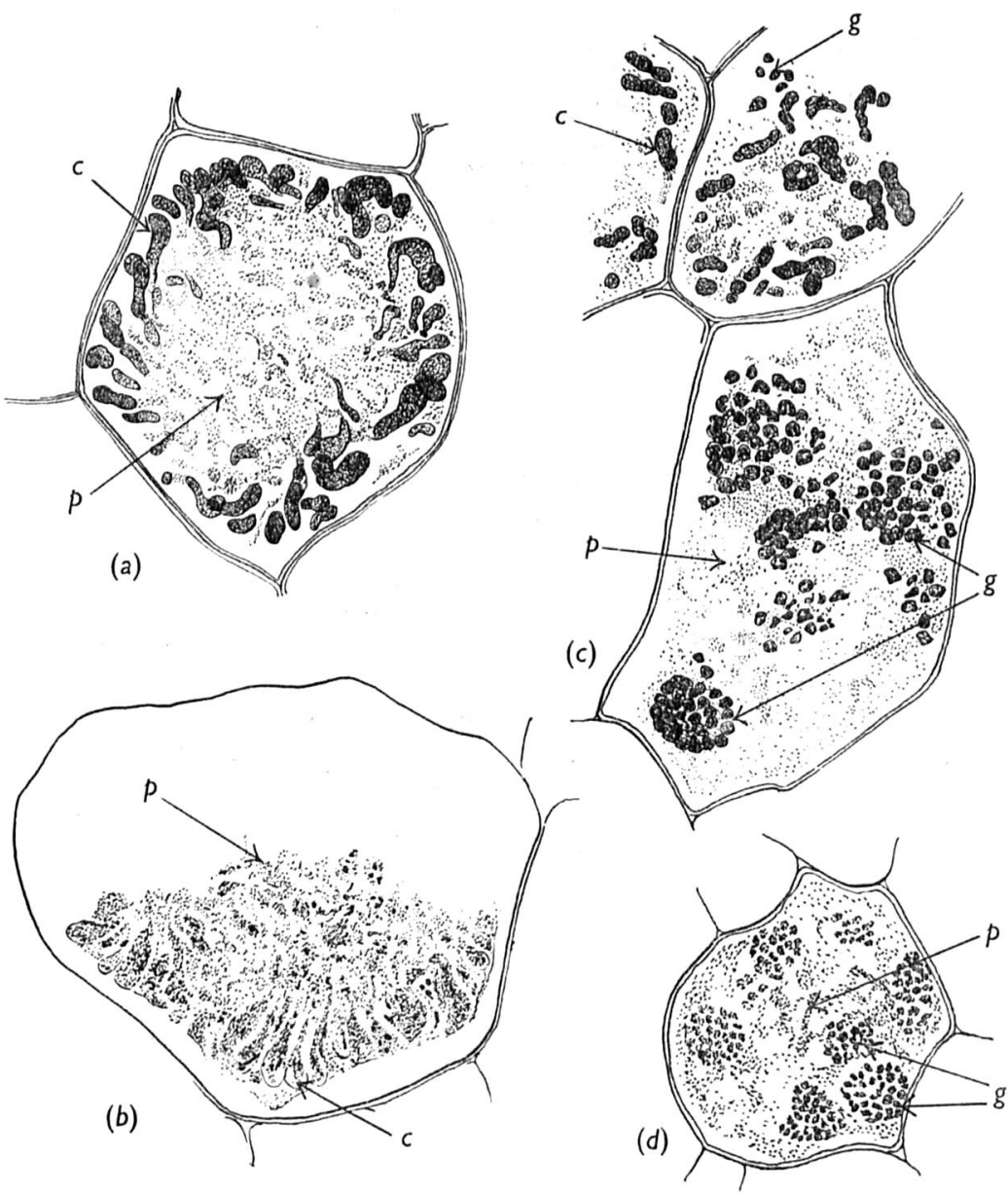

Fig. 8. Myrica gale. Production of granules. $(a)$ plasmodium $(p)$ of endophyte, forming clubshaped bodies $(c)$ at periphery. Stained gentian violet and light green. $\times 1050 .(b)$ similar cell (from same nodule) stained iron alum haematoxylin, showing granular contents of clubs. $\times 1050$. $(c)$ cells from same preparation as $(a)$ showing breaking up of clubshaped bodies to give 'bacteroid'-like granules $(g) . \times 1050 .(d)$ slightly later stage showing typical groups of granules. $\times 600$.

those formed within the vesicles of the other organisms (Fig. $8 c$ ). These clubshaped bodies must break up rapidly after formation as they are seldom seen. In most preparations only the plasmodial and the particle stages are present (Fig. $8 c, d ;$ Pl. 2, fig. 5). In squash preparations made from thin sections of fresh material, granules have frequently been seen to detach themselves from 
extruded masses of endophyte in the 'particle' stage and to move away slowly with a dancing movement. These particles are regular in size $(0.5 \mu$. long) and are tadpole-shaped with the posterior end pointed. In sections these masses of particles are seen to be still enclosed within the plasma membrane of the host, even though all other host cell contents have been consumed, so that it is difficult to see how the separate bodies migrate unless they do so by way of the pores previously made by the protoplasmic strands which presumably pierced both membrane and cell wall.

\section{DISCUSSION}

Relation between the endophytes of Elaeagnus, Hippophae, Alnus and Myrica. The morphology and general life history of these endophytes is similar. All show a plasmodial stage and all finally produce minute migratory particles. The endophytes of Elaeagnus and Hippophae are morphologically indistinguishable and almost certainly belong to the same species. In experiments which are still in progress, and which are to be repeated, cross-infection of these two hosts took place. The endophyte of Alnus is closely related but differs in the greater size of the vesicles and in the almost complete utilization of the protoplasm of the plasmodium during their formation. The endophyte of Myrica shows greater differences, notably the formation of the particles by the breaking up of club-shaped bodies, and may well be placed in a separate genus.

Nature of the endophyte. The endophytes of the root-nodules of species of Elaeagnus, Hippophae, Alnus, Myrica and Ceanothus have been variously interpreted as filamentous fungi (Hyphomycetes or Phycomycetes), bacteria, actinomycetes or members of the Plasmodiophorales.

The first record is that of Woronin (1866), who described an organism in the roots of Alnus glutinosa which he called Schinzia alni and interpreted as a filamentous fungus belonging to the Hyphomycetes. Moeller (1885) placed it in the Plasmodiophorales as Plasmodiophora alni (Woron) Moeller, and figured the migrating plasmodia. Schroeter (1889, 1897) agreed with Moeller and placed the endophyte of Elaeagnus angustifolia also in the genus Plasmodiophora (as P. elaeagni). Brunchorst (1886), however, could find no plasmodial stages in root-nodules of Alnus spp., Elaeagnus spp., Hippophae rhamnoides and Myrica gale and describes septate hyphae with terminal sporangia. He called these organisms Frankia subtilis and, notwithstanding their septate hyphae and small size, considered that they were related to the Mucorales or Saprolegniales. The views of Woronin and Brunchorst were then supported by Moeller (1890), who withdrew his earlier interpretation of the alder organism as a species of Plasmodiophora, and by Frank (1891) who considered Frankia subtilis to be a mycorrhizal fungus, although he pointed out the possibility of its being a thread-forming bacterium allied to Leptothrix. Atkinson (1892) demonstrated the resemblance of the organism inhabiting root-nodules of Ceanothus americanus to both Plasmodiophora brassicae and the alder organism described by Woronin as Schinzia alni and renamed Frankia subtilis by Brunchorst (1886). Hiltner (1896) claimed that the root-nodules of Alnus and Elaeagnus contained bacteria which he suggested were able to fix nitrogen. Chodat (1904) also 
inclined to the view that the endophytes were bacteria but with some myxomycete and actinomycete characters. That the question was at that time highly controversial is shown by Shibata's (1902) description of the Myrica endophyte as an actinomycete showing threads which broke up into bacteroidlike particles, by Björkenheim's (1904) claim to have seen fungal hyphae in the nodules, by Keissler's (1907) reference to the alder organism as Plasmodiophora alni and by Jaap's (1907) report of the occurrence of $P$. elaeagni in Switzerland. In a cytological investigation of the Plasmodiophoraceae Maire \& Tison (1909) excluded $\boldsymbol{P}$. alni and $\boldsymbol{P}$. elaeagni from this group and agreed with Shibata. They described tenuous branched filaments, containing chromatin granules but with no membrane and no definite nucleus, and developing terminal vesicles which segmented into a number of small irregular bodies. They renamed the Alnus and Elaeagnus endophytes Frankiella alni and F. elaeagni, and placed them in the Schizomycetes. Peklo (1910) supported Shibata as to the actinomycetous nature of the Myrica organism. Bottomley (1912, 1915) and Spratt (1912), however, claimed that the organisms in the root-nodules of Alnus, Elaeagnus, Myrica and Ceanothus were identical with the nitrogen-fixing bacteria in root-nodules of the Leguminosae. Both Bottomley and Spratt supported this view by claims of successful cross-inoculation experiments, but the reference which they give (Bottomley, 1907) does not mention such experiments.

Ziegenspeck (1929) and Borm (1931) sought to reconcile the opposing views of the various investigators by interpreting the 'plasmodial' stages as disintegration stages resulting from the development of a bacteriophage which was supposed to attack the nodule-forming bacteria. Schaede $(1933,1939)$ and Roberg (1934, 1938) have more recently supported Shibata's claim that these organisms are actinomycetes, but Keissler \& Lohwag (1937) have once more referred the alder organism to Plasmodiophora, while Sydow (1924) and Yendo \& Takase (1932) describe the Elaeagnus endophyte as Plasmodiophora elaeagni and Tetramyxa elaeagni respectively. Plotho (1941) claims to have isolated the alder organism and calls it Actinomyces alni. As an aid to clearness these conflicting views are classified in Table 1.

Claims that these organisms are filamentous fungi, either Hyphomycetes or Phycomycetes, are untenable since they are devoid of cell walls, and the protoplasmic strands are of variable width and of too small a size to be interpreted as fungal hyphae. The fact that a second endophyte, an arbuscularvesicular type of endotrophic mycorrhizal fungus, is frequently seen in roots of Elaeagnus angustifolia suggests that some earlier writers may have confused the two organisms. The fungus, however, is present in the cortex of otherwise normal roots and is never seen in the nodules.

The theory that the protoplasmic strands seen by many observers are the hyphae or threads of an actinomycete is more plausible. In fixed material, particularly of Myrica gale, the protoplasmic strands have something of the appearance of fine hyphae, but examination of material fixed with modern fixatives shows that there are no cross-walls and no obvious containing walls, and that the width and branching of the strands are very variable. In fresh material these strands are even less like hyphae. The striated appearance 
Table 1. Interpretation by various investigators of the nature of the endophytes of the root-nodules of non-leguminous plants

Interpretation of organism

Bacterium

\section{Host* \\ $A, E$ \\ $A, H$ \\ $C, M$ \\ $\boldsymbol{E}$}

Bacterium (attacked by bacteriophage)

Actinomycete

Filamentous fungus

Member of Plasmodiophorales
$A, H$

$A, H$

$\boldsymbol{M}$

$\boldsymbol{A}, \boldsymbol{E}$

$\boldsymbol{M}$

M

$A, H, M$

$\boldsymbol{A}, \boldsymbol{E}, \boldsymbol{H}$

$\boldsymbol{A}$

$\boldsymbol{A}$

$\boldsymbol{A}$

$A, E, H, M$

$\boldsymbol{A}, \boldsymbol{E}$

$\boldsymbol{M}$

$\boldsymbol{A}, \boldsymbol{E}$

$\boldsymbol{A}$

$A, E$

C

$\boldsymbol{E}$

$\boldsymbol{A}$

$\boldsymbol{E}$

$\boldsymbol{E}$

$A, E, H, M$
Reference

Hiltner (1896)

Chodat (1904)

Bottomley (1907, 1912, 1915)

Spratt (1912)

Ziegenspeck (1929)

Borm (1931)

Shibata (1902)

Maire \& Tison, (1909)

Peklo (1910)

Youngken (1919)

Schaede $(1933,1939)$

Roberg (1934, 1938)

Plotho (1941)

Woronin (1866)

Moeller (1890)

Brunchorst (1886)

Frank (1887, 1891)

Björkenheim (1904)

Zach (1908)

Moeller (1885)

Schroeter $(\mathbf{1 8 8 9}, \mathbf{1 8 9 7})$

Atkinson (1892)

Jaap (1907)

Keissler (1907)

Sydow (1924)

Yendo \& Takase (1932)

Hawker \& Fraymouth (present paper)

* $A=$ Alnus, $C=$ Ceanothus, $E=$ Elaeagnus, $\boldsymbol{H}=$ Hippophae, $M=$ Myrica

sometimes seen (Fig. 7) is due to the orientation of elongated particles along the direction of protoplasmic streaming across a cell from one pore to another. The protoplasm which fans out from the strands into the periphery of the cell or into a newly invaded cell is amorphous or indefinitely reticulate and thus bears no resemblance to the threads of an actinomycete. Attempts to interpret this amorphous mass as due to the disintegrating effect of a bacteriophage are unfortunate, as the 'plasmodial' stage actually precedes the protoplasmic strand and 'bacteroid' stages in the infection of any particular cell. The clubshaped bodies seen occasionally in the endophyte of $\boldsymbol{M}$. gale bear a superficial resemblance to those produced by certain actinomycetes. The production of groups of bacteroid-like particles from these bodies differs from the fission of the hyphae of true actinomycetes and is not paralleled in the development of the terminal 'clubs' of the latter. Moreover, the spherical vesicles of the endophytes of Alnus, Elaeagnus and Hippophae are unlike any structures seen in that group. Claims based on the reaction to the Gram stain and other stains are of little value since these reactions vary with the stage of development of the parasite.

The claim made by Bottomley (1912, 1915) and Spratt (1912) that the endophytes of root-nodules of non-leguminous plants are identical with Rhizobium 
leguminosarum is untenable in view of the prevalence of plasmodial and sporangial stages. The observations of these workers must have been based solely on cells in which the endophyte was represented by the small bacteroid-like particles formed from the spherical or club-shaped sporangia. At this stage many cells may contain these particles, which bear a superficial resemblance to $R$. leguminosarum but do not show the typical $\mathbf{T}$ and $\mathbf{Y}$ forms or the characteristic banding of the bacteroids of this organism. The fact that neither we ourselves nor Miss S. Mount (unpublished) have been able to cultivate these organisms by methods which sufficed for the isolation of the clover bacterium is additional evidence that they are not identical or even similar. Bottomley's claim (Spratt, 1912) that successful cross-inoculations were made between leguminous and non-leguminous hosts may have been based on faulty experimental technique. The present writers have reason to believe that the Elaeagnus and alder organisms are widely distributed in ordinary garden soil so that contamination might easily have taken place.

There remains the hypothesis that these organisms are members of, or at least closely related to, the Plasmodiophorales. The present observations are consistent with this view. The plasmodial stages are strikingly similar to those of Plasmodiophora brassicae with the exception of the greater tendency to form protoplasmic strands along the lines of flow. The development of these strands may be correlated with the degree of resistance of the host walls so that when resistance is considerable the area of penetration is reduced to a small pore and the flow of the plasmodium thus canalized into narrow streams. Thus in Myrica the endophyte shows the most definite development of protoplasmic strands or channels of flow and the walls of the host cell show the most definite reaction and rapidly become lignified in response to the presence of the parasite. In Alnus, which shows less distinct strands, resistance takes the form of the production of tannin cells and the walls of the invaded cells show only slight alteration and readily break down. In Elaeagnus and Hippophae, where the walls show little if any reaction to invasion and readily disintegrate, the invader shows very little development of protoplasmic strands and is frequently seen in the intercellular spaces. In all these, invasion is limited to the nodules which may, however, attain considerable size and complex branched structure. In Plasmodiophora brassicae, where resistance is slight and large areas of the root become involved, the cell walls offer little or no resistance to penetration, and consequently the plasmodium shows no development of protoplasmic strands corresponding to channels of flow but moves as an amoeboid mass.

The production of definite spherical sporangia by the endophytes of Elaeagnus, Hippophae and Alnus and of club-shaped ones by that of Myrica is no obstacle to the inclusion of these organisms in the Plasmodiophorales since modern work (Cook \& Schwartz, 1929, 1930; Cook, 1933; Karling, 1942) has suggested the existence of a sporangial stage in Plasmodiophora brassicae and in some other members of the group.

The sluggish movements of the released particles suggest that these may be myxamoebae rather than zoospores, but the presence or absence of flagella could not be determined with certainty. 
The chromatin granules present in the plasmodium are very small and no mitotic nuclear divisions were observed. Where nuclear divisions were observed (in Elaeagnus (Fig. 3; Pl. 1, fig. 4) and Hippophae) these were probably meiotic since they preceded the development of the sporangia. If they were reduction divisions, one would not expect them to be of the peculiar cruciform type described by some observers (Horne, 1930; Cook, 1928, 1933; Webb, 1935) as typical of mitotic divisions in some members of the Plasmodiophorales. No such cruciform divisions were seen in any of the nodule organisms here described.

Thus the morphology and life histories of the endophytes of Elaeagnus, Hippophae, Alnus and Myrica suggest that they are best placed in the Plasmodiophorales. The old names Plasmodiophora elaeagni and $\boldsymbol{P}$. alni have much to recommend them, while the Myrica organism might best be placed in a separate genus based on the club-shaped sporangia and the very marked protoplasmic strands. This organism is in many ways an approach to the actinomycetes and indicates a possible means of the evolution of coenocytic hyphae by the development of protoplasmic strands along lines of flow in a plasmodium and the subsequent condensation of the outer layers of these to form a membrane or wall. All these organisms show characters, such as the formation of definite sporangia, which approach the true fungi and they thus afford evidence in support of the view that the Plasmodiophorales are indeed primitive fungi.

The physiological nature of the host-parasite relationship is still a matter of doubt. Claims have been made that these organisms are able to fix nitrogen, but some observers have found no evidence of fixation. In our preliminary experiments and in those of Miss S. Mount (unpublished) seedlings of Hippophae rhamnoides grew to a height of 6 in. in sterilized sand without additional nitrates and were in no way inferior to inoculated seedlings with well-developed nodules, while seedlings of Alnus glutinosa in garden soil were equally vigorous whether they bore nodules or not. These experiments are being continued and extended. Naturally and artificially inoculated seedlings of these plants do not develop nodules until they have reached a considerable size, whereas inoculated clover seedlings develop them soon after germination. This suggests that the nonleguminous hosts are less dependent on, or even independent of, the nodule organism. The failure to isolate the endophytes by methods sufficing for the cultivation of Rhizobium suggests that the relationship may be one of obligate parasitism as with other species of Plasmodiophora. In these examples, however, the parasite is more or less controlled by the resistance of the host. In this connexion it is of interest that material of species of Ceanothus obtained by the writers and by Bottomley (1915) from various sources in England was devoid of root infection, but the plants were well developed, thus indicating that they were independent of the nodule-forming endophyte found by other workers in American material.

Thanks are due to the Director and Curator of the Royal Botanic Gardens, Kew, for seeds of various species and root material of Ceanothus spp., to Miss S. Mount for permitting us to use her slides of Hippophae rhamnoides for comparison with ours 
and for undertaking preliminary cultural studies, to Prof. Hewer of the Department of Pathology, University of Bristol, for allowing the use of his apparatus for taking photomicrographs and to Mr Rodgers for taking the photographs.

\section{REFERENCES}

Atrinson, G. F. (1892). The genus Frankia in the U.S.A. Bull. Torrey Bot. Cl. 19, 171.

Björkenheim, C. G. (1904). Beiträge zur Kenntnis des Pilzes in den Wurzelanschwellungen von Alnus incana. Z. PfIKrankh. 14, 129.

Borm, L. (1931). Die Wurzelknöllchen von Hippophae rhamnoides und Alnus glutinosa. Bot. Arch. 31, 441.

Botтomley, W. B. (1907). The structure of the root tubercles in leguminous and other plants. Rep. Brit. Ass. p. 693.

Воттомцеу, W. B. (1912). The root-nodules of Myrica gale. Ann. Bot., Lond., 26, 111.

Воттомцеу, W. B. (1915). The root-nodules of Ceanothus americanus. Ann. Bot., Lond., 29, 506.

Brunchorst, J. (1886). Über einige Wurzelanschwellungen besonders diejenigen von Alnus und den Elaeagnaceen. Unters. bot. Inst. Tübingen 2, 151.

Chodat, R. (1904). Sur les parasites des racines d'Alnus, de Rhamnus et d'Hippophae. Bull. Herb. Boissier, 2ème serie, 4, 296.

Cook, W. R. I. (1928). The methods of nuclear division in the Plasmodiophorales. Ann. Bot., Lond., 42, 347.

Cook, W. R. I. (1933). A monograph of the Plasmodiophorales. Arch. Protistenk. 80, 179.

Cook, W. R. I. \& Schwartz, E. J. (1929). The life history of Sorosphaera radicale sp.nov. Ann. Bot., Lond., 43, 81.

Cook, W. R. I. \& Schwartz, E. J. (1930). The life-history, cytology and method of infection of Plasmodiophora brassicae (Woron)., the cause of finger-and-toe disease of cabbages and other crucifers. Philos. Trans. B, 218, 283.

Frank, B. (1887). Sind die Wurzelanschwellungen der Erle und Elaeagnaceen Pilzgallen? Ber. dtsch. bot. Ges. 5, 50.

Frank, B. (1891). Über die auf Verdauung von Pilzen abzielende Symbiose, der mit endotrophen Mykorhizen begabten Pflanzen, sowie der Leguminosen und Erlen. Ber. dtsch. bot. Ges. 9, 244.

Hiltner, L. (1896). Über die Bedeutung der Wurzelknöllchen von Alnus. Landre. VersSta. 46, 153.

Horne, A. S. (1930). Nuclear division in the Plasmodiophorales. Ann. Bot., Lond., 44, 199.

JAAP, O. (1907). Beiträge zur Pilzflora der Schweiz. Ann. mycol., Berl., 5, 246.

Karling, J. S. (1942). The Plasmodiophorales. New York (privately published).

Keissler, K. (1907). Beitrag zur Kenntnis der Pilzflora Kärntens. Ann. mycol., Berl., 5, 220.

Keissler, K. \& Lohwag, H. (1937). Fungi. Symb. Sinicae 2, 2. (Not seen, reference in Karling (1942), p. 36.)

KrebBer, O. (1932). Untersuchungen über die Wurzelknöllchen der Erle. Arch. Mikrobiol. 3, 588.

Maire, R. \& Tison, A. (1909). La cytologie des Plasmodiophoraceae et la classe des Phytomyzinae. Ann. mycol., Berl., 7, 242.

Moeller, H. (1885). Plasmodiophora alni. Ber. dtsch. bot. Ges. 3, 102.

Moeller, H. (1890). Beitrag zur Kenntnis der Frankia subtilis Brunchorst. Ber. dtsch. bot. Ges. 8, 215.

Pekro, J. (1910). Die pflanzlichen Aktinomykosen. Zbl. Bakt. (2. Abt.), 27, 451.

Plotho, O. V. (1941). Die synthese der Knöllchen an den Wurzeln der Erle. Arch. Mikrobiol. 12, 1. 
Roberg, M. (1934). Über den Erreger der Wurzelknöllchen von Alnus und den Elaeagnaceen Elaeagnus und Hippophae. Jb. wiss. Bot. 79, 472.

Roberg, M. (1938): Uber den Erreger der Wurzelknöllchen europaische Erlen. Jb. reiss. Bot. 86, 344.

SASS, J. E. (1940). Elements of Botanical Microtechnique. New York: McGraw Hill.

SchaEde, R. (1933). Über die Symbioten in den Knöllchen der Erle und des sandornes und die cytologischen Verhaltnisse in ihnen. Planta, 19, 389.

Schaede, R. (1939). Die Actinomyceten-symbiose von Myrica gale. Planta, 29, 32.

Schroeter, J. (1889). In Cohn's Krypt. Fl. Schlesiens, 3, 134.

Schroeter, J. (1897). In Engler and Prantl's Nat. Pflanzenf. 1 (1), 7.

Servettaz, C. (1909). Monographie des Eléagnacées. Beih. bot. Zbl. 25, 1-420.

Shibata, K. (1902). Cytologische Studien über d. endotrophen mykorrhiza. Jb. wiss. Bot. 37, 643.

Spratr, E. R. (1912). The morphology of the root tubercles of Alnus and Elaeagnus and the polymorphism of the organism causing their formation. Ann. Bot., Lond., 26, 119.

Sxdow, H. (1924). Beiträge zur Kenntnis der Pilzflora Neu-Seelands, 1. Ann. mycol., Berl., 22, 293.

Thornton, H. G. (1949). Problems presented by nodule bacteria and the legume host. Agric. Progr. 24, 1.

WebB, P. C. R. (1935). The cytology and life history of Sorosphaera veronicae. Ann. Bot., Lond., 49, 41.

Woronın, M. (1866). Über die bei der Schwazerle und der gewöhnlichen Gartenlupine auftretenden Wurzelanschwellungen. Mem. Acad. Sci. St Petersburg 7 (10), 13.

Yendo, Y. \& TAKase, T. (1932). On the root-nodule of Elaeagnus. Bull. Seric. Silk Industr., Uyeda, 4, 5 (Japanese with English summary.)

YounGken, H. W. (1919). The comparative morphology, taxonomy and distribution of the Myricaceae of the Eastern United States. Contr. bot. Lab. Univ. Pa. 4, 339-400. (Not seen; reference in Metcalfe, C. R. \& Chalk, L. 1950. Anatomy of the Dicotyledons. Vol. 2, p. 1293. Oxford.)

$\mathrm{Z}_{\mathrm{ACH}}, \mathbf{F}$. (1908). Über den Wurzelknöllchen von Elaeagnus angustifolia und Alnus glutinosa lebenden Fadenpilz. S.B. Akad. Wiss. Wien (Abt. I), 117, 973.

ZIEGENSPECK, H. (1929). Die cytologischen Vorgänge in den Knöllchen von Hippophä̈ rhamnoides (Sanddorn) und Alnus glutinosa (Erle). Ber. dtsch. bot. Ges. 47, 5 (50).

\section{EXPLANATION OF PLATES}

\section{Plate 1. Hippophae rhamnoides and Elaeagnus spp.}

Fig. 1. Median longitudinal section of root-nodule of Hippophae rhamnoides. G, growing point; $P$, zone in which host cells contain young plasmodium; $S$, zone in which endophyte is in the form of spherical sporangia; $D$, zone in which endophyte is disintegrating. $\times 18$.

Fig. 2. Median longitudinal section of root-nodule of Elaeagnus macrophylla. Lettering as in Pl. 1, fig. 1. $\times 25$.

Fig. 3. E. macrophylla cells from edge of sporangial zone. p, plasmodium of endophyte; $n$, host nucleus; $h$, remains of host cytoplasm; $s$, sporangia of endophyte. $\times 400$.

Fig. 4. E. angustifolium. Fully developed plasmodium of endophyte showing nuclear divisions (probably meiotic). $\times 800$.

Plate 2. Alnus glutinosa and Myrica gale.

Fig. 1. Infected cells in longitudinal section of root-nodule of Alnus glutinosa. Endophyte in vesicular or sporangial stage. $v$, vesicles; $s t$, protoplasmic strands connecting endophyte in adjacent cells; $t$, tannin (?) cells of host; sg, starch grains in host cell. $\times 400$. 
Fig. 2. 'Bacteroid' stage of endophyte in $A$. glutinosa. These bacteroid-like granules ( $g$ ) are formed in the vesicles or sporangia, disintegrating remains of plasmodium with empty vesicles (see fig. 1 ). $\times \mathbf{4 0 0}$.

Fig. 3. Plasmodium of endophyte of Myrica gale advancing towards tip of nodule. 1, 2 and 3 are host cells in various stages of infection. Cell 1 is filled with endophyte, cell 2 is not completely filled and the plasma membrane $(m)$ of the host is still visible, cell 3 has only just been entered. $s t$, protoplasmic strands of endophyte; $p$, plasmodium, fanning out from these. Note tubular thickened mass of host cell wall $(w)$ at point where parasite has entered cell 2 from cell $1 . \times 500$.

Fig. 4. Club-shaped bodies (c) of the endophyte of $M$. gale forming at periphery of plasmodium $(p)$ (stained gentian violet). 'Bacteroid' stage $(g)$, at lower left hand corner. $\times 200$.

Fig. 5. Groups of 'bacteroids' $(g)$ formed in cells of nodule of $M$. gale. $\times 200$.

(Received 23 June 1950) 
Journal of General Microbiology, Vol. 5, No. 2
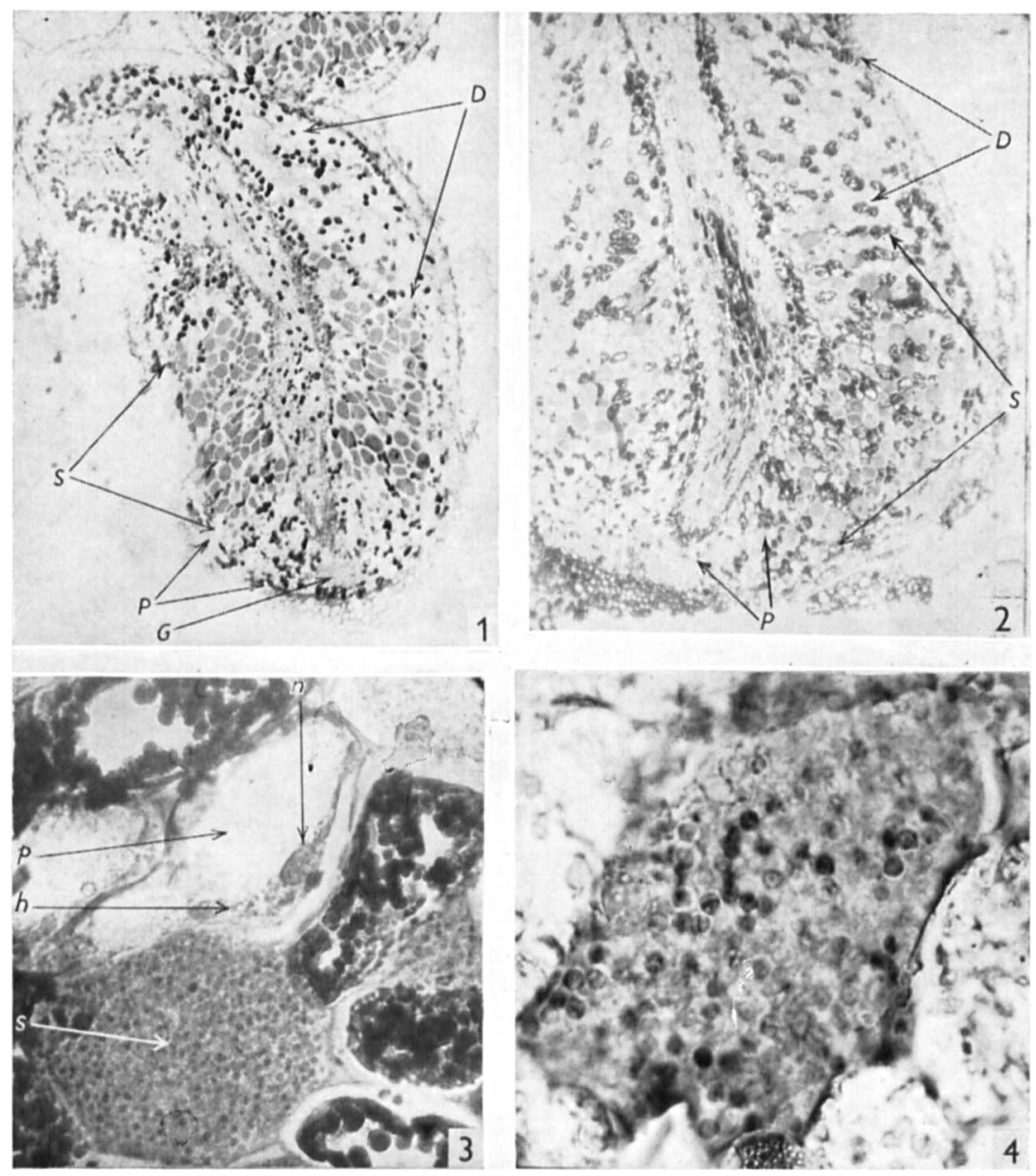

Lilian E. Hawker \& Joan Fraymouth-PIasmodiophorales in root-nodules. Plate 1 
Journal of General Microbiology, Vol. 5, No. 2
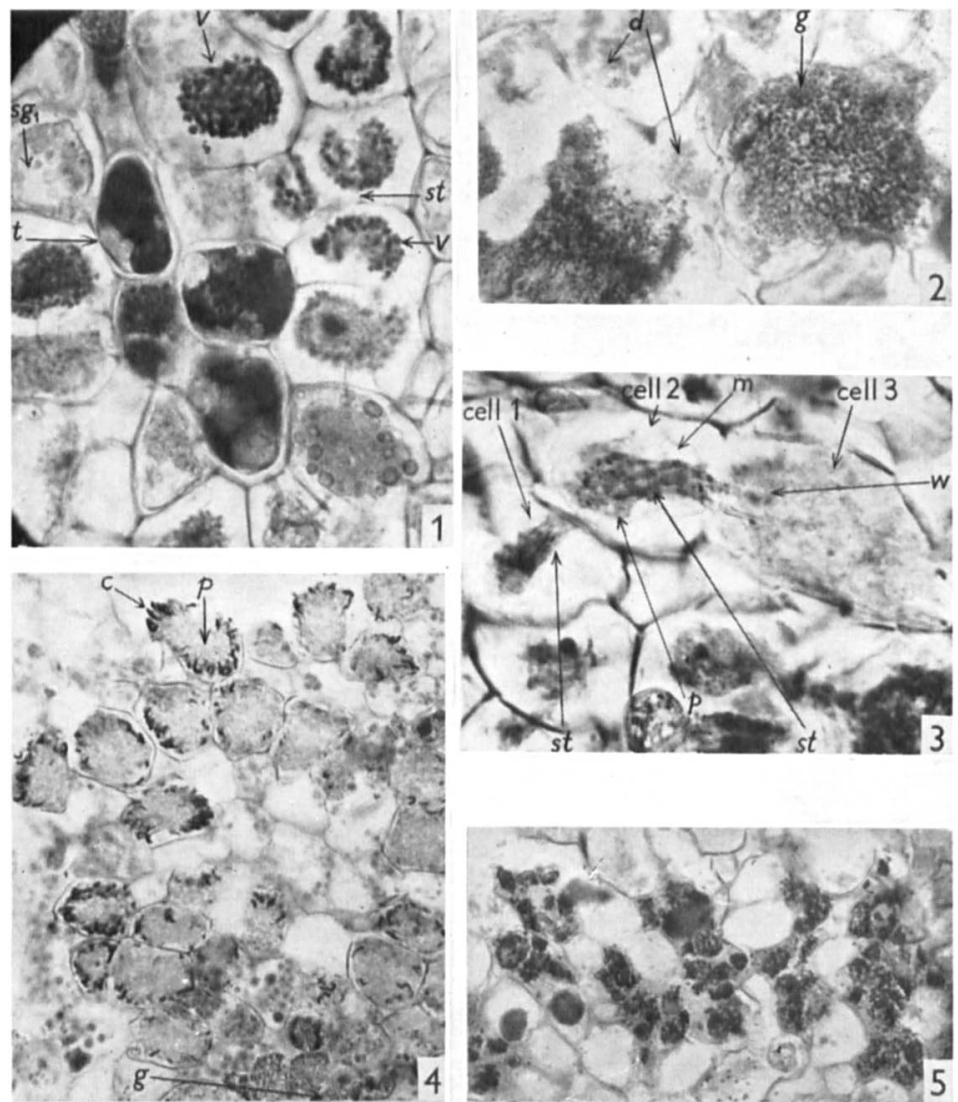

Lilian E. Hawker \& Joan Fraymouth-Plasmodiophorales in root nodules. Plate 2 